\title{
AMINO ACID PROFILE OF EARTHWORM AND EARTHWORM MEAL (Lumbricus rubellus) FOR ANIMAL FEEDSTUFF
}

\author{
L. Istiqomah, A. Sofyan, E. Damayanti and H. Julendra \\ Division of Feed and Animal Nutrition \\ Research Unit for Development of Chemical Engineering Processes \\ Indonesian Institute of Sciences (LIPI) \\ Jl. Jogja - Wonosari Km. 31, Gading, Playen, Gunungkidul, Yogyakarta, 55861 \\ Corresponding Email: ps_uty@yahoo.com
}

Received November 3, 2009; Accepted November 30, 2009

\begin{abstract}
Earthworm meal (Lumbricus rubellus) has become one of natural material that could be used as feed additive. Powdering method of earthworm was done by using formic acid addition. The study was carried out (1) to evaluate the essential amino acid profile of earthworm and earthworm meal, (2) to calculate the value of essential amino acid index (EAAI) of both materials. A modified EAAI equation was developed from the essential amino acid profile of earthworm and earthworm meal. The result showed that essential amino acid of earthworm was dominated by histidine ( $0.63 \%$ of dry matter basis), meanwhile the earthworm meal was dominated by isoleucine $(1.98 \%$ of dry matter basis). The non essential amino acid of earthworm and earthworm meal was dominated by glutamic acid $(1.52 \%$ and $3.60 \%$ of dry matter basis respectively). The value of essential amino acid index obtained from earthworm meal was higher $(58.67 \%)$ than those from earthworm $(21.23 \%)$. It is concluded that powdering method of earthworm by using formic acid addition had higher amino acid balance than earthworm.
\end{abstract}

Keywords: amino acid, earthworm meal, feed additive L. rubellus

\section{INTRODUCTION}

Fish meal is the conventional source of animal protein in poultry feed and it has been valued for its balanced amino acids, vitamin content, palatability and growth factors (Tacon, 1993). Because of the increasing cost of high quality fish meal required for poultry feed and due to declining stocks of fish from capture fishery and competition for feed in animal husbandry, there is now need to search for alternative sources of animal protein for poultry feeds especially in developing countries (Sales and Janssens, 2006). These alternatives must be able to supply adequate indispensable and dispensable amino acid requirements of the fish or sufficient amino nitrogen to enable their synthesis.

Many scientists have reported the possible use of some alternative animal protein feedstuffs to fish meal such as earthworm meal (Hilton, 1983; Yaqub, 1991; Edwards, 1998; Sogbesan and Ugwumba, 2006; Sogbesan and Madu, 2008). As a feed supplement, it has been found that earthworm is equal to or surpass fish meal and meat meal as an animal protein source for poultry.
The biological value has positive correlation with amino acid balance (Rama Rao et al., 1964). Meanwhile the amino acid balance could be calculated by Essential Amino Acid Index (EAAI) (Oser, 1951 cit. Mitchell and Block, 1946). The increase of EAAI value will enhance nutrient absorption (Raghunath and Narasinga Rao, 1984). There were some treatments that could increase the EAAI value in physically or mechanically way, one of that was powdering method.

Previous study showed that earthworm meal of Lumbricus rubellus had $65.63 \%$ crude protein content (Damayanti et al., 2008), earthworm meal of Lumbricus terestris contained $32.60 \%$ protein (Julendra, 2003), and earthworm meal of Perionyx excavatus contained $57.2 \%$ crude protein and had complete amino acid (Tram et al., 2005) Although the special quality of earthworm meal has been known well as potential fish meal replacement as protein source (Yaqub, 1991), but it's still necessary to study about the essential amino acid composition in earthworm meal.

The experiments were carried out (1) to evaluate the profile of essential amino acid composition of earthworm and earthworm meals, 
(2) to the value of essential amino acid index (EAAI) of both materials.

\section{MATERIALS AND METHODS}

\section{Earthworm Meal Preparation}

Based on United States patent US005128148A (Ishii et al., 1992), disclosed processing for the production of dried earthworm powder which comprises the steps of leaving a species of $1 \mathrm{~kg}$ earthworms Lumbricus rubellus, Allolobophora caliginosa or Pheretima comunissima in $2-4$ litres fresh water or slightly acidic aqueous solution such as malate acid, citrate acid, phospate acid, tartate acid, lactic acid and succinate acid with comparison of $\mathrm{pH}$ average $5.2-6.2$, kept in $8-15^{\circ} \mathrm{C}$ temperature for $2.5-$ 18 hours until the alimentary canal thereof is freed of soil, wet-grinding the earthworm, and freezedrying and then vacuum drying the resulting suspension under a vacuum of $10 \mathrm{mmHg}$ or below for 10 to 100 hours while raising the temperature gradually from $-60^{\circ} \mathrm{C}$ to $80^{\circ} \mathrm{C}$. This steps would produced dried earthworm powder.

Based on Edwards (1985) method, the earthworm washed using water to separate manure from outside skin and fecal (fecal mud) then kept in cold water $\left(14^{0} \mathrm{C}\right)$ for 24 hours. Formic acid (80\%) was added around 3\% of earthworm body weight. The earthworm was grinded and dried using oven $50^{\circ} \mathrm{C}$ for 12 hours and sheaved to achieve homogenize powder.

In this study, earthworm meal (L. rubellus) was produced by using modified method from Edwards (1985). Earthworm sample was separated from media then washed using water and kept in the refrigerator $\left(4^{\circ} \mathrm{C}\right)$ for 12 hours. Formic acid $(3 \% \mathrm{v} / \mathrm{w})$ was added into earthworm and dried by using oven $50^{\circ} \mathrm{C}$ for $10-12$ hours. Dried sample was grinded and sheaved become to particle size $\pm 40 \mathrm{mesh}$. Nutrient composition proximately of earthworm meal was summarized on Table 1.

\section{Analyzing Amino Acid}

Amino acid of earthworm meal was analyzed by using High Performance Liquid Chromatography (HPLC). Chloride acid 6N (10 $\mathrm{ml}$ ) was added into 2 gram of earthworm meal and kept in highly temperature of disclosed reaction cylinder. Sample was hydrolysed by autoclave $\left(110^{\circ} \mathrm{C}\right)$ for 20 hours then preserved in well-closed state at room temperature. After that, sample was evaporated in $50^{\circ} \mathrm{C}$ temperature then
Table 1. Nutrient Composition of Earthworm Meal

\begin{tabular}{lc}
\hline Composition & Earthworm meal \\
\hline Moisture & 9.03 \\
Crude Protein & 63.06 \\
Ether Extract & 18.5 \\
Crude Fiber & 0.19 \\
Nitrogen Free Extract & 12.41 \\
Organic Matter & 94.16 \\
Ash & 5.81 \\
\hline
\end{tabular}

* Dry matter basis (\%)

neutralized by $\mathrm{NaOH} 6 \mathrm{~N}$ addition. The sample was filtered by $0.45 \mu \mathrm{m}$ millex filter paper using vacuum filter. Before the sample was injected to the HPLC, $275 \mu \mathrm{L}$ OPA solution $(0,01 \mathrm{~g}$ phetaldialdehyde, $9 \mathrm{ml}$ methanol, $40 \mathrm{ml}$ buffer borax $\mathrm{pH}$ 9.1, $100 \mu \mathrm{L}$ 2-mercaptoethanol were added into $25 \mu \mathrm{L}$ sample, vortex and being reacted for 5 minutes. The HPLC operation was C18 column, move phase A: Sodium acetate $\mathrm{pH}$ 5.0; B : $80 \mathrm{MeOH} / 15$ Buffer acetate / 5 THF $(\mathrm{v} / \mathrm{v} / \mathrm{v})$, rate flow $1.5 \mathrm{ml} / \mathrm{minute}$, detector : fluorescence $\lambda$ excitation $340 \mathrm{~nm} ; \lambda$ emission 450 $\mathrm{nm}$.

\section{Observed Variables}

Variables measured were essential amino acid composition in earthworm and earthworm meals and also essential amino acid index in both materials. Amino acid composition was analyzed by HPLC. EAAI value was calculated by Oser equation (1951) cit. Mitchell and Block (1946) with mathematical model:

$\log E A A I=\frac{1}{10}\left[\log \frac{100 \times A 1}{A t 1}+\log \frac{100 \times A 2}{A t 2}+\ldots+\log \frac{100 x A n}{A t n}\right]$

Note:

A1: first, ...(1,2,3,4......n) essential amino acid rate from experiment sample

At1: first, ...(1,2,3,4......n) essential amino acid rate from standard (whole egg)

\section{RESULTS AND DISCUSSION}

Earthworm meal L. rubellus had high protein content and it was very important as nutrient source for animal. Protein content of earthworm meal was equal to fish meal $(55-60 \%$ crude 
protein) as protein source for poultry feed. Earthworm meal had also containing bioactive 'lumbricin' in which able to inhibit pathogenic bacteria (Cho et al., 1998). Sofyan et al. (2008) reported that earthworm meal with or without chitosan capable to reduce $E$. coli colonization and improve protein retention in broiler chicken.

Formic acid addition (3\%) into the earthworm meal could increase the crude protein rate and produced low $\mathrm{pH}$. The formic acid addition into earthworm before entering the grinding process was estimated could protect the earthworm meal from decomposer microbes, therefore it capable to maintain the highly protein content and also bioactive compound.

Earthworm L. rubellus contained 'lumbricin I' which had antibacterial activity, included in peptide group which contained 62 amino acids (Salzet et al., 2006). Amino acid utilized as proteins are primary constituents of structural and protective tissues, including skin, feathers, bone, ligaments, as well as muscles and organs. Amino acids are used as poultry feed supplement for optimum performance and also used in livestock health care (NOSB, 2001). As feed supplement amino acids form protein. Of the 22 amino acids found in body proteins, the National Research Council lists 13 as essential in poultry diets, and these must be consumed in feed. These 13 are: arginine, glycine, histidine, isoleucine, leucine, lysine, methionine, cystine, phenylalanine, proline, threonine, tryptophan, and valine (NRC 1994). Five of them that are deemed critcial in poultry rations are methionine, cystine, lysine, tryptophan, and arginine (North, 1990).

Amino acid analysis with HPLC showed that earthworm and earthworm meal L. rubellus had essential and non essential amino acid content (Table 2). The highest essential amino acid of earthworm was dominated by histidine $(0.63 \%$ of dry matter basis) and earthworm meal was dominated by isoleucine $(1.98 \%$ of dry matter basis). Histidine was essential for protein synthesis, involved in carnitine and haemoglobin synthesis. It was effective in alergic disease and tension of the autonomic nervous system, meanwhile isoleucine was involved in protein synthesis, energy production and muscle building.

Tram et al. (2005) reported that the highest essential amino acid composition of $P$. excavatus was leucine $(3.47 \%$ and $0.76 \%$ of dry matter basis respectively). The non essential amino acid of earthworm and earthworm meal was dominated by glutamic acid $(1.52 \%$ and $3.60 \%$ of dry matter basis respectively). This result also similar to previous experiments reported by Tram et al (2005) that the highest non essential amino acid composition of Perionyx excavatus was glutamic

Table 2. Amino acid composition of earthworm and earthworm meal

\begin{tabular}{|c|c|c|c|c|}
\hline Amino Acid* & $\begin{array}{l}\text { Earthworm } \\
\text { L. rubellus }\end{array}$ & $\begin{array}{l}\text { Earthworm meal } \\
\text { L. rubellus }\end{array}$ & $\begin{array}{l}\text { Earthworm meal } \\
\text { P. excavatus } 1)\end{array}$ & $\begin{array}{c}\text { Promin earthworm } \\
\text { flour }^{2} \text { ) }\end{array}$ \\
\hline \multicolumn{5}{|l|}{ Essential } \\
\hline Phenyalalanine & 0.45 & 1.03 & - & - \\
\hline Valine & 0.52 & 1.3 & - & - \\
\hline Methionine & 0.35 & 1.72 & 1.2 & 0.22 \\
\hline Isoleucine & 0.47 & 1.98 & 2.74 & 0.47 \\
\hline Threonine & 0.45 & 1.03 & 1.25 & 0.52 \\
\hline Histidine & 0.63 & 1.91 & 2.87 & 0.26 \\
\hline Arginine & 0.56 & 1.24 & 0.4 & 0.65 \\
\hline Lysine & 0.51 & 1.43 & 0.13 & 0.76 \\
\hline Leucine & 0.54 & 1.16 & 3.47 & 0.76 \\
\hline Cysteine & 0.31 & 0.39 & - & - \\
\hline Tyrosine & 0.43 & 0.82 & - & - \\
\hline \multicolumn{5}{|l|}{ Non Essential } \\
\hline$\overline{\text { Aspartic acid }}$ & 0.98 & 2.38 & 3.18 & 1.16 \\
\hline Glutamic acid & 1.52 & 3.6 & 7.13 & 1.42 \\
\hline Serine & 0.54 & 0.7 & 2.45 & 0.5 \\
\hline Glycine & 0.35 & 0.55 & - & - \\
\hline Alanine & 0.32 & 0.99 & - & - \\
\hline Proline & 0.54 & 0.71 & 1.81 & 0.53 \\
\hline
\end{tabular}

* Dry matter basis (\%); 1) Tram et al., 2005 
acid $(7.13 \%$ and $1.42 \%$ of dry matter basis). Glutamic acid was involved in protein synthesis and as source of energy for cells lining the intestine. Facilitates immune function and improve anti-inflammatory effects, aids in preventing and healing of peptic ulcer and ulcerative colitis.

The high essential amino acid composition of earthworm meal would produce great result when added in animal feedstuff ratio. By protein content rich with amino acids, the earthworm meal presents around $98 \%$ of absorption by animal organism due the balance between vitamins and amino acids (Promin, 2006).

According to Table 2, the amino acid contents of earthworm meal were varied depending on species and food source. However, earthworms have been found to accumulate and concentrate methionine and lysine as limiting amino acid found in ecosystem in proportions greater than for other amino acids (Pokarzhevskii, et al., 1997). Earthworm meal contains all the essential amino acids required in feedstuff. A shortage of the limiting amino acid will constrain animal growth, reduce feed efficiency, and in extreme cases cause a nutritional deficiency. NRC requirements for amino acids and protein are designed to support maximimum growth and production. The recommended levels for methionine in poultry depend on species, stage, and level of feed consumption. For chickens, recommendations for layers range from $0.25 \%$ to $0.38 \%$ and for broilers $0.32-0.50 \%$ (NRC, 1994).

Amino acid composition both essential and non essential of earthworm meal were higher than those of the earthworm, except cysteine composition which is almost similar $(0.31 \%$ of dry matter basis of earthworm and $0.39 \%$ of dry matter basis of earthworm meal). Powdering method could increase the amino acid composition because this method used heating process.

Quality of powdering method could be performed by amino acid balance which indicated by essential amino acids index (EAAI) value (Mitchell and Block, 1946). Highly EAAI value on earthworm meal showed that earthworm meal had higher amino acid balance than earthworm (Table 3).

Besides powdering method by formic acid (3\%) addition, the amino acid balance (EAAI) could be increased by another physical and mechanical treatment such as fermentation and also pelleting (Mitchell and Block, 1946). This
EAAI value means that essential amino acid more balance and it could increase the biological value of feed material, absorption and also supporting the poultry growth (Rama Rao et al., 1964; Raghunath and Narasinga Rao, 1984).

Tabel 3. Essential Amino Acid Index (EAAI)

\begin{tabular}{lc}
\hline Material & EAAI Value (\%) \\
\hline Earthworm L. rubellus & 21.23 \\
Earthworm meal L. rubellus & 58.67 \\
Whole egg (standard) & 100 \\
\hline
\end{tabular}

\section{CONCLUSION}

Amino acid composition both essential and non essential of earthworm meal were higher than those of earthworm. The value of essential amino acid index obtained from earthworm meal process was higher $(58.67 \%)$ than earthworm $(21.23 \%)$. Powdering method of earthworm by using formic acid had higher amino acid balance than earthworm.

\section{REFERENCES}

Cho, J.H., C.B. Park, Y.G. Yoon and S.C. Kim. 1998. Lumbricin I, a novel proline-rich antimicrobial peptide from the earthworm: purification, cDNA cloning and molecular characterization. Biochim. Biophys. Acta. 1408 (1): 67-76.

Cho, I.H., E.S. Choi, H.G. Lim and H.H. Lee. 2004. Purification and characterization of six fibrinolytic serine-proteases from earthworm Lumbricus rubellus. J. Biochem. Mol. Biol. 37 (2): 199-205.

Damayanti, E., H. Julendra and A. Sofyan. 2008. Antibacteria activity of earthworm meal (Lumbricus rubellus) with different methods to the Escherichia coli. Proceedings. National Food Seminar, Yogyakarta, January 17, 2008. P. 54-60.

Edwards, C. A. 1985. Production of Feed Protein from Animal Waste by Earthworms. Phil. Trans. R. Soc. Lond. B 310: 299 - 307.

Edwards, C. A. 1998. The use of earthworms in the breakdown and management of organic wastes, in C.A. Edwards (ed.). Earthworm Ecology: 327-376. Boca Raton, FL: CRC Press. 
Hilton, J.W. 1983. Potential of freeze-dried worm meal as a replacement for fishmeal in trout diet formulations. Aquaculture. 32: 227-283.

Ishii, Y and Hisashi M. 1992. Process for the production of dried earthworm powder and antihyperlipemic, antidiabetic, antihypertensive and antihypotensive preparation containing dried earthworm powder as active ingredients. United States patent US005128148A.

http://www.patents.com/patents-by-category/ chemistry. (accessed: July 9, 2009).

Julendra, H. 2003. Antibacterial activity test of earthworm meal as broiler feedstuff to the bacteria growth of Salmonella pullorum with in-vitro method. Proceedings. Study Report of Research and Development in Technical Science and Knowledge (IPT) 2003.

Mitchell, H, H, and R, J, Block, 1946, Some relationships between the amino acid content of proteins and their nutritive values for the rat. J. Biological Chemistry. 163: 599.

North, M.O. and D. D. Bell. 1990. Commercial Chicken Production Manual, 4th ed. Van Nostrand Reinhold, New York.

National Organic Standards Board [NOSB]. 2001. Methionine. Technical Advisory Panel Review for the USDA National Organic Program. Organic Materials Review Institute, United States, May 21, 2001. P. 120.

National Research Council [NRC]. 1994. Nutrient Requirements of Poultry. 9th Ed. National Academy Press, Washington DC.

Oser, B. L. 1951 Method for integrating essential amino acid content in the nutritional evaluation of protein. J. Am. Dietetic Assn. S7: 396.

Pokarzhevskii, A.D., D.P. Zaboyev, G.N. Ganin, and S.A. Gordienko. 1997. Amino acids in earthworms: Are earthworms ecosystemivorous? J. Soil Biol. Biochem. 29: 559-567.

Raghunath, M. and B.S. Narasinga Rao. 1984. Relationship between relative protein value and some in vitro indices of protein quality. J. Biosciences. 6 (5): 655-661.

Rama Rao, P.B., H.W. Norton and B.C. Johnson.
1964. The amino acid composition and nutritive value of proteins. v. amino acid requirements as a pattern for protein evaluation. J. Nutrition. 82: 88-92.

Sales, J. and Janssens, P.J.G. 2003. Nutrient requirements of Ornamental fish .Review. Aquatic Living Resour., 16: 533-540.

Salzet, M., A. Tasiemski, E. Cooper. 2006. Innate immunity in lophotrochozoans: The annelids. Current Pharmaceutical Design, 12 No. 00. P: $1-8$

Sogbesan, A.O. and C.T. Madu. 2008. Evaluation of earthworm (Hyperiodillus euryaulos, clausen, 1914; oligocheata: eudrilidae) meal as protein feedtuffs in diet for Heterobranchus longifilis valenciennes, 1840 (teleostei, clariidae) fingerlings under laboratory condition. J. Environmental Sci. 2(1): 23-31.

Sogbesan, A.O. and Ugwumba, A.A.A. 2008. Nutritional Evaluation of Termite (Macrotermes subhyalinus) Meal as Animal Protein Supplements in the Diets of Heterobranchus longifilis (Valenciennes, 1840) Fingerlings. Turkish J. Fisheries. Aquatic Sci. 8: 149-157.

Sofyan, A., E. Damayanti and H. Julendra. 2008. Antibacterial activity and retained protein of earthworm meal (Lumbricus rubellus) as feed additive combined with chitosan. J. Ilmu Ternak Vet. (JITV) 13(3): 182-188.

Tacon, A.G.J. 1993. Feed ingredients for warm water fish: fish meal and other processed feedstuffs. FAO Fisheries Circular No: 856, FAO Rome, 64 pp.

Tram, N.D.Q, L.D. Ngoan and B. Ogle. 2005. Culturing earthworms on pig manure and the effect of replacing trash fish by earthworms on the growth performance of Catfish (Clarias macrocephalus $x$ Clarias gariepinus). http://www.mekam.org/msc200305/theses05/tram_p2.pdf (accessed: July 9, 2009).

Yaqub, H. 1991. Earthworm and maggot meals as a potential fish meal replacement. Thesis. Institute of Renewable Natural Resources U.S.T., Kumasi, Ghana. 